\title{
References
}

Callisen, K. 1929: Petrographische Untersuchung einiger Gesteine von Nordgrönland. Meddr Grønland 71 (6), 217-255.

Christie, R. L. 1967: Bache Peninsula, Ellesmere Island, Arctic Archipelago. Mem. geol. Surv. Can. 347, 63 pp.

Cowie, J. W. 1961: Contributions to the geology of North Greenland. Meddr Grønland 164 (3), $47 \mathrm{pp}$.

Dawes, P. R., Rex, D. C. \& Jepsen, H. P. 1973: K/Ar whole rock ages of dolerites from the Thule District, western North Greenland. Rapp. Grønlands geol. Unders. 55, 61-66.

Henriksen, N. \& Jepsen, H. F. 1970: K/Ar age determinations on dolerites from southern Peary Land, North Greenland. Rapp. Gronlands geol. Unders. 28, 55-58.

Jepsen, H. F. \& Kalsbeek, F. 1979: Igneous rocks in the Proterozoic platform of eastern North Greenland. Rapp. Grønlands geol. Unders. 88, 11-14.

Koch, L. 1933: The geology of Inglefield Land. Meddr Gronland 73 (1), 2, 38 pp.

Peel, J. S., Dawes, P. R., Collinson, J. D. \& Christie, R. L. 1982: Proterozoic - basal Cambrian stratigraphy across Nares Strait: correlation between Inglefield Land and Bache Peninsula. In Dawes, P. R. \& Kerr, J. W. (edit.) Nares Strait and the drift of Greenland: a conflict in plate tectonics. Meddr Grønland, Geoscience 8.

Rex, D. C. \& Dobson, M. H. 1970: Improved resolution and precision of argon analyses using an AEI MS10 mass spectrometer. Eclog. geol. Helv. 63, 275-280.

Troelsen, J. C. 1950: Contributions to the geology of Northwest Greenland, Ellesmere Island and Axel Heiberg Island. Meddr Grønland 149 (7), 86 pp.

Vidal, G. \& Dawes, P. R. 1980: Arcritarchs from the Proterozoic Thule Group, North-West Greenland. Rapp. Grønlands geol. Unders. 100, 24-29.

D. C. R., Department of Earth Sciences, University of Leeds, Leeds LS2 9JT,

U.K.

\section{Towards a refined stratigraphy for the basalts of Svartenhuk Halvø}

\section{Karl A. Jørgensen}

Mapping of the Tertiary basalts of the Svartenhuk Halvø area (Larsen, 1981a,b) at a scale of 1:100000 (sheet $71 \mathrm{~V} \mathrm{~N}$ ) was continued during the 1981 field season (fig. 5). The work was concentrated on the northern and north-western part of the area, with emphasis on detailed profiles rather than on general mapping. A total of 11 profiles were measured, with an aggregate thickness of $6000 \mathrm{~m}$. The profiles are divided into two including (a) four main profiles which were intensely sampled and (b) seven auxilliary profiles, which have only been moderately sampled. The measured profiles give an overlapping view of the middle formation of Larsen (1981), while the lower and upper formations have only been partially measured and sampled (fig. 5). 

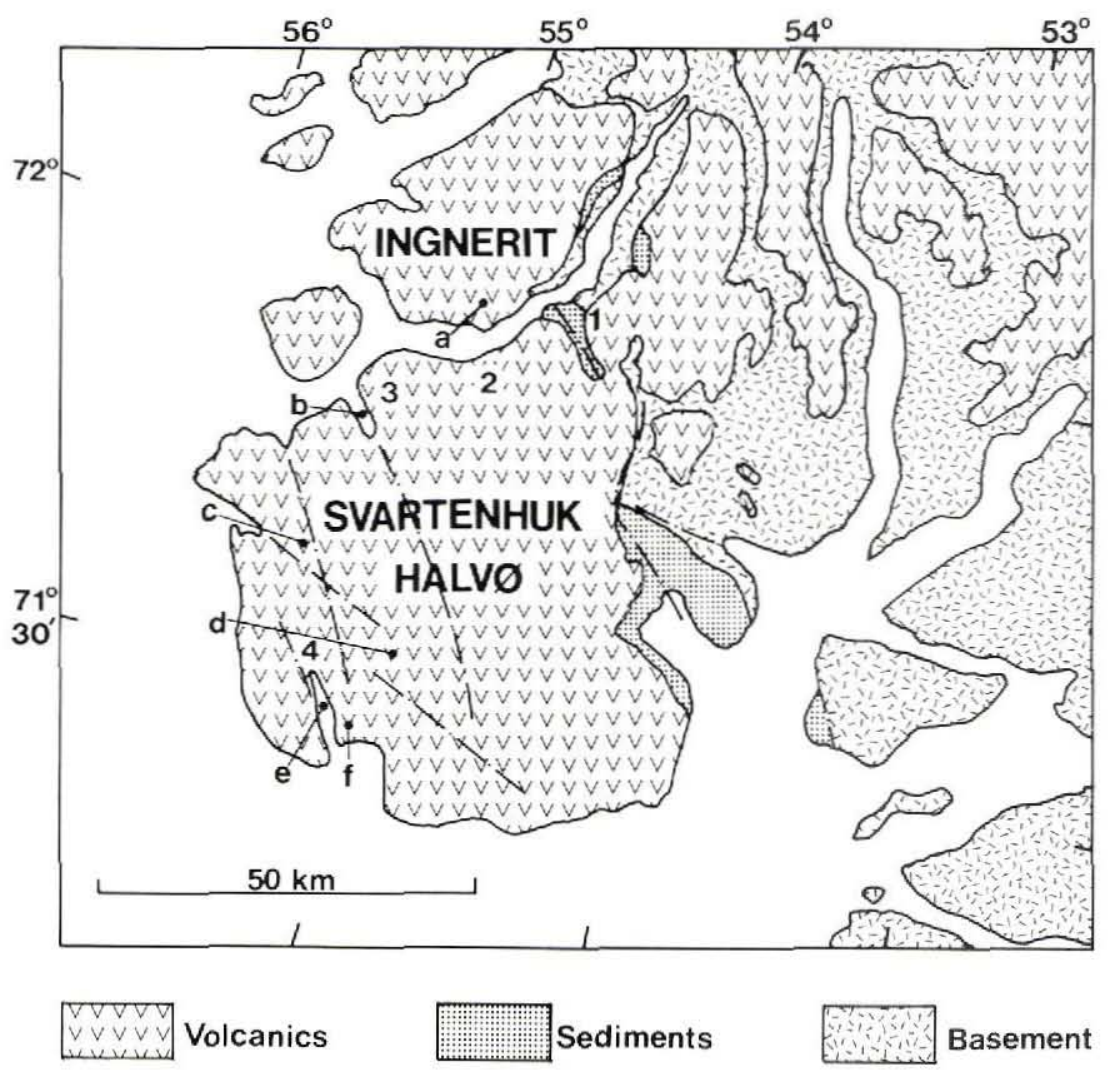

Fig. 5. Simplified geological map of Svartenhuk Halvø and surroundings (from Clarke \& Pedersen, 1976) showing position of main faults and profiles. I Simiútap kûa east, 2 Nerutussoq, 3 Amitsup kûa and 4 Quagssugârssuit. Other localities mentioned in text: a Páinivik, b Amitsup, c Maligissap kûa, d Aputitût, e Arfertuarssuk, f Kugssineq.

The middle formation shows a general increase in thickness from NE to SW from approximately $400 \mathrm{~m}$ east of Simiútap kûa, to $800 \mathrm{~m}$ in the Nerutussoq area, and possibly even more further west. The thickening is due to an increase in the number of flows and not to an increase in flow thickness which in fact seems to decrease. A similar thickening seems to occur from north to south within the Amitsup kûa valley, indicating that the formation attains its greatest thickness in the central part of the area. The middle formation can be further subdivided on the basis of prominent massive, brown, feldspar-phyric flows, of which two exist within the formation. The lower sequence is the $\beta_{1}$ horizon of Larsen (1981a), which directly overlies the picrites of the lower formation in the south-west part of the area. In the north-east part it is separated from the main picrites by a thick interbasaltic sedimentary sequence (Pulvertaft \& Clarke, 1966; Andreasen, 1981) and the overlying mixed sequence of hyaloclastites and pillow lavas. In the profiles east of Simiútap kûa the sequence contains four thick flows, while in the Nerutussoq area this number has increased to seven. 
This sequence is followed by a minor break and is succeeded by picritic basalts at first with thick entablature zones, alternating with more resistant aphyric flows. In the middle of the formation a new sequence of massive, brown, feldspar-phyric flows occurs with a prominent tuff at the base. In the central part of this sequence shallow water sediments occur along with lavas with thick entablatures and pillow lavas, and in the south wall of Páinivik mountain on Ingnerit, a minor angular unconformity apparently occurs at this level. The upper part of the sequence is interbedded with olivine-plagioclase-phyric pahoehoe lavas and more massive aphyric lavas.

The base of the upper formation in this area is formed by a very prominent feldspar-phyric lava with thick entablature, overlying a thick red tuff which probably correlates with the basal hyaloclastite in the Aputitût section (Larsen, 1981a). Above this lava follows a thick sequence of yellow-topped, somewhat vesicular, feldspar-phyric lavas, occasionally interlayered with thin sequences of olivine basalt flows. The top of this sequence has not been investigated on the north coast, but in the Kugssineq fault belt, west of the Aputitût massif, the sequence terminates with a thick, massive columnar jointed, sparsely feldspar-phyric lava followed by a sequence of thick, red-topped lavas commonly interlayered with feldsparphyric pahoehoe lavas. This is succeeded by a thick sequence of olivine-feldspar \pm pyroxenephyric pahoehoe lavas. This sequence may be silicified in the top. It underlies a $30 \mathrm{~m}$ thick reworked hyaloclastite which outcrops poorly in the Arfertuarssuk fjord area, and forms the base of the Quagssuqârssuit series of differentiated lavas (Pulvertaft \& Clarke, 1966; Münther, 1973; Larsen, 1981a). The Arfertuarssuk trachyte (Nieland, 1931) directly overlies the hyaloclastite in the Arfertuarssuk fjord area, but further inland this is replaced by a massive mafic lava. The differentiated highest member of olivine-feldspar-pyroxene-phyric basalts only has a limited lateral extent, and gives way to picritic basalts further north. In contrast the trachyte has been traced $15 \mathrm{~km}$ northwards to the valley of Maligíssap kûa, where it is cut by a major transverse fault system. Bottom relations of the trachyte, found in the fjord section, indicate that it is a strongly fines-depleted (Walker et al., 1980) rheomorphic ignimbrite, and thus may have had a large areal distribution with a good marker potential. The thickness of the highest member is a few hundred metres and in the upper part only monotonous, sparsely feldspar-phyric, massive lavas occur. They may cap the basalt pile, which is indicated by similar-looking, undisturbed dykes cutting the faulted terrain in the westernmost part of the area.

\section{References}

Andreasen, F. 1981: Sedimentological observations in Cretaceous and Tertiary rocks in the northern part of the West Greenland sedimentary basin. Rapp. Gronlands geol. Unders. 105, 26-27.

Clarke, D. B. \& Pedersen, A. K. 1976: Tertiary volcanic province of West Greenland. In Escher, A. \& Watt, W. S. (edit.) Geology of Greenland, 365-385. Copenhagen: Geol. Surv. Greenland.

Larsen, J. G. 1981a: Stratigraphy and structure of Tertiary volcanic rocks of southern and eastern Svartenhuk Halvø south of $72^{\circ} \mathrm{N}$ lat. and some areas north of $72^{\circ} \mathrm{N}$ lat. Unpubl. int. GGU report, 49 pp.

Larsen, J. G. 1981b: A preliminary study of flow directions of Tertiary hyaloclastites and pahoehoe lava flows on Svartenhuk Halvø, West Greenland. Rapp. Grønlands geol. Unders. 105, 28-32. 
Münther, V. 1973: Results from a geological reconnaissance around Svartenhuk Halvø, West Greenland. Rapp. Grønlands geol. Unders. 50, 26 pp.

Nieland, H. 1931: Beitrag zur Kenntnis der Deckenbasalte von Westgrönland. Chemie der Erde 6, 591-612.

Pulvertaft, T. C. R. \& Clarke, D. B. 1966: New mapping on Svartenhuk peninsula. Rapp. Grønlands geol. Unders. 11, 15-17.

Walker, G. P. L., Wilson, C. J. N. \& Froggat, P. C. 1980: Fines-depleted ignimbrite in New Zealand the product of a turbulent pyroclastic flow. Geology 8, 245-249.

Geologisk Museum,

Øster Voldgade 5-7, $D K-1350$ Kobenhavn $K$.

\section{Investigations on the Precambrian rocks of Svartenhuk Halvø, central West Greenland}

\section{Bas van den Eeckhout and John Grocott}

Precambrian rocks occur within an area of $600 \mathrm{~km}^{2}$ in eastern Svartenhuk Halvø. A preliminary geological account of the southern half of this area is given here. The work is part of the mapping programme aimed at the production of the $1: 100000$ sheet $71 \mathrm{~V} .1 \mathrm{~N}$.

The Precambrian rocks east and south of Svartenhuk Halvø have been studied in some detail by Henderson \& Pulvertaft (1967), but until the summer of 1981, apart from the pioneering work of Steenstrup (1883) and preliminary petrographic descriptions of the metasediments by Noe-Nygaard (Rosenkrantz et al., 1942), the Precambrian of Svartenhuk Halvø had only been studied in the detail necessary for the production of the 1:500000 map sheet Mârmorilik - Melville Bugt. The map area consists of a gneissic basement with a metasedimentary cover (fig. 6).

\section{Metasediments}

The cover is dominated by a lithologically monotonous sequence of alternating metamorphsed sandstones and shales, called the Nûkavsaq Formation (Henderson \& Pulvertaft, 1967). Leucocratic, amphibole-bearing bands of uncertain origin lie parallel to bedding within the sequence. Good examples of sedimentary structures indicating the way-up are infrequent, but of these graded bedding is the most useful. Channelling was only observed at one locality, and no certain bottom structures survived the deformation. On each side of Kangiussap auvfâ in the southern part of the area the sediments have a marked brownweathered appearance and include garnet-mica schists, hornblende schists and quartzites. A similar but more varied sequence is present at the gneiss/sediment contact. Such rocks are exposed at the lowest structural levels within the cover, and may be members of the Qeqer- 